\title{
RESEARCH ON CINEMA AND ITS ROLE IN PRESERVING THE EGYPTIAN FOLKLORE BY APPLYING IT TO SAMPLES OF FILMS
}

\author{
Yaqout Al-DEEB *
}

Academy of Arts, Alexandria, Egypt

\begin{abstract}
The study was divided into six chapters as follows: Chapter One: Customs and traditions on the Egyptian screen (A) The concept of customs and traditions $(B)$ An inventory of Egyptian customs and traditions $(C)$ customs and traditions on the cinema screen Chapter II: Proverbs and popular sayings in Egyptian films (A) on the concept of proverbs and popular sayings (B) Examples of Egyptian proverbs and sayings $(C)$ Egyptian films, proverbs and popular sayings Chapter III: Stories and folk tales in Egyptian cinema $(A)$ on the concept of folktale $(B)$ The most popular Egyptian folk tales $(C)$ Egyptian films dealing with folk tales and stories Chapter IV: Popular characters on the Egyptian cinema screen (A) The concept of popular personality (B) Models of popular figures and heroes $(C)$ Films dealing with popular personality, Chapter V: Popular films in Egyptian films (A) on the concept of popular folk art (B) Popular folk art in Egypt (C) films made by the art of watching Chapter VI: The musical and lyrical heritage in the Egyptian cinema (A) Folk music and singing in Egypt (B) Popular music in Egyptian films (C) Popular songs in Egyptian cinema.

Keywords

Cinema, Preserving, Egyptian, Folklore, Films.
\end{abstract}

\section{Introduction}

In this study, the researcher concludes with the following conclusions:

(1) Cinema can preserve the Egyptian folklore, and the technique of combining image and sound, which is unique to this property (with television), without other means of preserving the other heritage. (2) Cinema alone, through which we can see the popular folklore, and in a more attractive, effective and influential way, to a degree that surpasses the way of mere description of the reader on the pages of books. (3) Through the cinema, the viewer can see the vocabulary and materials of the heritage, a picture, and hear a voice, and read characters ... This feature unique to the cinema without other means of preserving the other heritage.

The relationship of Egyptian cinema with folklore and its various forms remains an old one, as old as the emergence of the cinema industry in Egypt. The relationship has continued throughout the history of Egyptian cinema and continues, thanks to the efforts of many filmmakers and directors, among them we mention: Youssef Chahine (Struggle in the Valley), Salah Abu Seif (The Second Wife Film), and Henry Barakat (The Haram Film, Ezz El Din Zulfikar (Doaa Al Karawan movie), Atef Salem (Khan Al Khalili film), Kamal Attia (Al Postaji movie), Hassan Al Emam (in Naguib Mahfouz trilogy), Kamal Attia Qandil Umm Hashim film), Hussam El Din Mostafa (Adham Al Sharqawi film), Hussein Kamal (We Do Not Plant 
Thorns), Hani Lashin (Al-Aragouz Film), Khairy Beshara (The Ring and the Bracelet), Ali Badrakhan (Shafika and Matwali), Ahmed Yahya (Love Does Not See the Sun), Radwan AlKashef (Arak Al-Balah Film) ... and others.

From all of the above, we can say that there are a large number of Egyptian films, whose subjects depend on heritage and popular legacies, which reflects the extent of cinema's interest in heritage and its forms, and on the other hand, an explanation of the role that Egyptian cinema can play in preserving heritage The same, as one of the methods of distinct preservation (image and sound), in contrast to other methods of preservation represented in paper publications, regardless of the position of filmmakers regarding its content or method of eating it. Based on the foregoing, the problem of this research lies in how cinema can be used to preserve the Egyptian heritage, simulate it on the screen with sound and image, in addition to stating the position on the heritage itself, and to achieve the call to purify it from impurities, which may give it some of the negatives attached to it, which It is counted on the Egyptian heritage, at a time when it is one of the most important sources of inspiration for many filmmakers in Egypt and the Arab world.

\section{Chapter 1}

\section{Customs and traditions on the Egyptian screen:}

A- The concept of customs and traditions Sociologists differentiate between the term habits and the word traditions, although the two words are closely related to each other, but they point out that habits are "the group of things that we are accustomed to doing from a young age", and they are passed down from generation to generation. Traditions, for it is "the cultural heritage that we inherited from the ancient fathers, and it became for us like old books or references, which we return to when needed". Customs and traditions are among the social behaviors that we grew up with from childhood, which formed our mental and psychological awareness, and it is noticeable that the most groups of Egyptian society adhere to customs and traditions, at the present time they are those who have become old. In the era of scientific progress, technological development and the Internet, the matter of preserving our popular heritage in general has become difficult, and is rejected by the youth of this time, while some argue that the importance of customs and traditions is mainly represented in that they constitute a sign and an identity for the Egyptian society, and distinguish it among societies Arabic.

B- An inventory of Egyptian customs and traditions, regardless of the negatives or positives, the customs and traditions that we find in Egyptian society, but we refer to some of them that we still practice in our daily life, and perhaps the most prominent of them are: sitting in the entrances to homes, the curiosity of some to know the secrets of others, the role of the 
matchmaker and their relationship With families and families, the baby's week, the visiter's delicacy for psychological treatment, waiting for the grandchild's (son's son) to come, going to the village book, the groom and bride's inscriptions, blessing with the righteous saints of God and sheikhs, marrying the girl to her uncle, taking revenge, killing the wrong girls, marrying the eldest daughter first Male purification parties, female circumcision, resorting to impostors and the impoverished, harem council, inheriting the profession from fathers and grandparents, ugly exposing the liar, the shaking bowl, the inability to leave the widow, shortening after work for men, the henna night for the bride, the mechanical hymen breaking, the midwife's preference (The birth) Ali the doctor, the significance and its role in buying and selling ... etc.These customs and traditions, which have spread in Egyptian society, since ancient times.

C- Customs and traditions on the cinema screen. Customs and traditions are clearly visible in so-called social reality films, in particular, but this does not prevent other kinds of films from being included in them such as comedies, political, historical, or even food and show films. It is noticeable that Egyptian cinema, throughout its history, has been full of dealing with the vast majority of our customs and traditions, which are characteristic of Egyptian society, in all social events, whether in the city and urban society, the countryside (in my tribe and the sea), or the coastal and desert communities. Among the most prominent Egyptian films, which reflect customs and traditions in Egypt, we mention:

\section{Chapter II}

\section{Proverbs and popular sayings in Egyptian films:}

A- On the concept of proverbs and popular sayings, in his book "Introduction to Folklore", Ahmed Ali Morsi indicates that folklore "includes myths and folk tales of all kinds, jokes and folk proverbs, riddles, hymns, sophistication, spells, curses, methods of greeting in reception and farewell, satirical formulas, and manipulation of words, The department's styles include folk customs, folk dance, popular drama, mummering and folk arts, folk medicine and folk beliefs, folk music and its instruments, folk songs of all kinds, popular anthropomorphic expressions, folk similes, metaphors and metaphors, place names, nicknames, titles, folk poetry, and writings by Gravestones are written on tombstones ... and others, as it includes: games, gestures, symbols and jokes, the origin of popular words, methods of preparing food, forms of embroidery and needlework, patterns of folk houses and buildings, calls from vendors, traditional comments made after sneezing or belching, and popular celebrations in Occasions such as holidays, birthdays, circumcision, marriage ... etc. " We conclude from this overarching definition - that "proverbs and popular sayings" is one of the heritage materials that successive 
generations have preserved, generation after generation.

B- Examples of proverbs and Egyptian folk sayings Cinema is one of the important means of preserving such materials (proverbs and popular sayings), and among the popular proverbs in films, which we hear from the characters: the sad people get happy, because they are killed, the girl suffers from her mouth, the girl looks to her mother The white shark is useful in the black day, patience is the key to relief, contentment is an indefinite treasure. My son Adam runs monsters. Other than your livelihood, you will not go wild. In the nape is a mirror, and in the back is a serpent. Mossi counted him, pharaoh rises, and other popular proverbs. Among the sayings and anecdotes: They are considered from the ruling, but they are often said in the Arabic language, not in the colloquial dialect, and to comment on an event, including: This cub is from that lion, a day for you and a day for you, he pauses and does not neglect, the madmen in bliss, your horse tongue Your Lord is in the lookout, the path of repentance, the people are shrines, their plagues are great, injustice is forbidden, they came to the al-Aqra, the hair of the daughter of the Sultan, Al-O, and the monkey took over his beauty, the little fortune he met the bone in the tripe, the wisdom of the lunatics, the one who stings from the drink blows into Yogurt ... and others

\section{Chapter III}

\section{Folk stories and tales in Egyptian cinema:}

A- On the concept of the folk tale: Abd al-Hamid Yunus indicates in "Dictionary of Folklore" that the term "folklore" indicates that it is not intended merely to inform, narrate and stories, because the tale is a language indicating imitation or imitation ... Then the term evolved and the expression varied In it, even the simulation interfered with the news, narration and stories. After that, the story was linked to types of narration that sometimes diverge from historical truthfulness, and perform the function of entertainment and entertainment at other times. "In another definition, it may be expressed more clearly and in a concept close to achieving the purpose of the research, "Naaman al-Hiti "says:“" The popular story A fictional genre that does not have a composer: because it is the result of multiplying a large number of colors of oral storytelling to which the narrators add, alter, or cut from it ... and it expresses aspects of the group's personality, so its attribution to a specific author is considered a form of plagiarism, but it remains In their nature is popular. "Thus we see that" Hiti "means that these stories are passed down from generation to generation, and then they do not remain the same, as they are subject to deletion, addition or modification, but in the end they retain their spirit that is consistent with the environment to which they belong. Especially the human group that produces it, as well as its distinctive character as a free deposit of folk fiction, it narrates 
important events of popular characters.

The definition of "Numan al-Hiti" is consistent with the English dictionaries 'definition of the folk tale as" a tale that the people believe as a fact, and it develops with the ages and circulates it around the corner. It is also concerned with pure historical incidents, or the heroes who make history. "From this definition, we find that folk tales can tell historical stories whose facts came in a past time by historical figures as well, some of whom may contribute to making history, these characters that bear the features of a folk hero, and that people attach to their stories and their biographies. The story or the folk story is distinguished by the fact that the process of deletion, addition and modification takes place first according to the memory of its narrator, or whoever reformulates it in a work of art, unlike the story and direct oral narration on the tongue of the narrator and the poet of Rababa. He may perform this process: the plastic artist in his sculptures and paintings, or the playwright or dramatic author. Or, the maker of the cinematic film ... and in all cases, these artistic works can employ this or that story artistically, aesthetically, or intellectually and expressively in another way, starting from the text of the story: the blogger or the oral. The folk story is also distinguished by being a mirror that reflects the aspects of the age and the life features of the society that It found in it, in addition to narrating real or imaginary events or a mixture of them, that could establish the values, customs and traditions of society, and not deviate from what is prevalent in it. This means, as Firas AlSawah sees it, that the folk tale is distinguished from the fairy tale by its social obsession, and its themes that It is almost confined to matters of social and family relations, especially in relation to it, and it keeps its protagonists closer to the ordinary people we encounter in our daily endeavor".

B- The most famous Egyptian folk tales, Egypt, since the era of the Pharaohs, and until modern times, has been full of many folk tales, for example, but not limited to, without our ancestors, the Pharaohs, those stories on the walls of the temples, the most prominent of which are: "Johnny's conquest" (the seizure of Jaffa), and the quarrel of Hor West (the struggle of "Hor" with his uncle "Set"), "the eloquent peasant, the farmer's complaint or the pleading of the farmer)," Sinuhe "(the homesickness, and the story of" truth and lies "(justice between the two brothers: truth and lie) ... and others Among the pharaonic folk stories, and in modern times, the Egyptians recorded many folk tales, which were subsequently collected and coded, in what is called "oral literature," and perhaps the most famous of those stories: "Tales of Shattar and Al-Ayyin" (such as "Ali Al-Zeeb / The Noble Knight") Tales of mysteries, "Tales of the Jinn and the Angels," "Hamza al-Bahlwan's biography," "The Camel of Saleh," "The Tale of Zelizela," "Ali Baba and the Forty Thieves," "Marzouq Al-Ataqi” (Taj Al-Jazeera / Al- 
Sultania), "Cinderella" Maarouf Al-Iskafy, "Shater Hassan," "Saad El-Yateem," "Hassan and Naima," "Adham El-Sharkawy," "Shafiqa and Metwally" ... and other popular stories that dealt with Egyptian cinema with Bite from it, and it turned into movies

\section{Chapter IV:}

\section{- Popular characters on the Egyptian cinema screen:}

A - The concept of the popular personality The researcher believes that "the popular personality can be defined as a personality whose behaviors are based on the popular heritage, depending on the specificity of the environment and identity." In the field of diagnostic arts (cinema, theater, aragouz, shadow fiction, etc.), these characters represent the main engine of action and a tool that reveals conflict. These characters are distinguished by a special performance that reflects the heritage environment in which they live, such as: the village mayor, the sheikh of the guard, the gendarme, the patrol soldier, the government pen employee, the sheikh of the book, the mosque muezzin, the storyteller, the mother-in-law, the fatwa of the neighborhood, the Harafish, the dervish, The charlatan and the juggler, the traveler, the people who collect cotton ... in addition to the traditional characters known by name in our folk tales, and other characters that have been covered in feature films.

B- Models of popular personalities and heroes The history of Egyptian folk literature is full of the names of many characters, who can be considered popular personalities, according to the previous definition developed by the researcher. And there are the characters that were worthy of associating the name of the folk tale with its name, such as: "Ali Al-Zeebiq," "Hamza AlBahlawan," "Zelizleh," "Saad Al-Yatim," Adham Al-Sharqawi, and "Al-Maghanati | Hassan, Marzouq Al-Ataki, Ali Baba, Maarouf Al-Iskafi, Al-Shater Hassan, Cinderella, Yassin and Bahia... and other popular heroes.

\section{Chapter V:}

\section{Popular watching arts in Egyptian films:}

A - On the concept of popular watching art: On the concept of popular watching art, it means the popular art of watching, those that target the popular classes in the Egyptian society, whether those who live in the countryside or urban or in the Badia regions. On the other hand, researcher "Muhammad Fathi Al-Senussi" points out that popular watching arts are those arts that do not contain in their components the foundations and elements of drama and theater, with their precise scientific meaning and recognized artistic characteristics, such as: Aragouz, shadow imagination, and the world box. It is worth noting that these arts are sought by their creators to the audience in their whereabouts, and not to go - as it is - to see them.

B- Folklore watching arts in Egypt, which are of particular interest to us in this study: "Al- 
Aragouz", "Shadow Fantasy," and "Dunya Box", which deal with topics, stories or scenes from the Egyptian folklore. Through "The Art of Al-Aragouz", stories are presented: "Shater Hassan", "Yassin and Bahia". He also dealt with stories from the lived reality about folkloric folk figures such as: "the village mayor," "the sheikh of the country," "the sheikh of al-Ghafar," "the village barber," "the wife of al-Araguz," "Samson the mighty," "Antar and Abla," "Hassan and Naima. "... and other characters.

And the art of "shadow imagination", which is one of the most famous folk watching art in Egypt. It is an art that came to us from the far eastern countries (China and India) through Persia, and spread and became famous in the Mamluk era in particular in the eleventh century $\mathrm{AD}$, and its representations were known In the name "Babat" (plural Babat), as is the case in naming the tales of Araguz. Among the most famous of his shadow fantasy dramas are: "The Spectrum of Imagination", "Wonderful Gharib", "Orphan and Orphan Goods", and other skits. As for the art of the Dunya Fund "it does not know precisely the date of the origin of this art or its original home, despite its wide spread throughout our Arab world. It is one of the forms of traditional folklore art that has spread especially in Egypt since the end of the nineteenth century. Inside it, viewers follow it. Famous folk tales depicting heroic and equestrian themes such as: the biography of Antara bin Shaddad, Al-Zanati Khalifa, the story of Princess Dhat Al-Himma, Samson and Delilah, Al-Zeer Salem, Al-Zahir Baybars, the biography of Bani Hilal, the story of Hamza Al-Bahrawan, Ali Al-Zeebq, the biography of Saif bin Dhi Yazan, Aziza Yunus, and the stories of the prophets.

\section{Chapter VI:}

\section{Musical and lyrical heritage in Egyptian cinema:}

A - Folk music and singing in Egypt The earliest interest in popular music and singing in Egypt was evident through the book of folk songs in Upper Egypt, presented by the French archaeologist, Gaston Maspero in 1914, which included three sections: The first is the songs of "Marriage and Circumcision", The second is about "funeral mourning," and the third section is about "work and pilgrimage." In 1932 AD another book was published that complemented "Maspero" under the title "In addition to studying the Egyptian song" by a Greek doctor who lives in Egypt called "Mavras" who was traveling between The villages and hamlets of Egypt, reflecting his knowledge of rural life and its traditions, as he collected in his book the songs of the events of unknown author, which belong to the Egyptian folklore. The musical group was arranged in the following manner: work songs (fishermen, builders, collecting cotton ... etc), occasion songs (Al-Sebou ', Eid, Al-Shabaka, Al-Henna, Al-Zaffa, Laylat Al-Dakhla and AlSabahiya, the songs of the epics Abu Zaid Al-Hilali, Hassan and Naima, Antara Bin Shaddad), 
dance songs (horse dance, Al-Tahteeb, Al-Ghawazi). Her words are known to the author, and they are Unknown, and the last type is what is called "the folk song that is difficult for us to return to a specific author, and which has become one of the pillars of folklore or" folk traditions. " The folk song may be represented when the narrative songs that tell with words and the musician are called short stories that do not reach in length to popular biographies or epics. Rather, it is closer to the story that deals with a number of characters, and it is more like mawal, such as the songs: "Adham Al Sharqawi", "Hassan and Naima" "Shafiqa and Matwali", Yassin and Bahia "and the song" Aziza and Younis "." Ibrahim Zaki Khorshid "indicates that he also includes in the popular songs the calls of the sellers for their goods, the zajal and the mawal, and the popular Bedouin songs.

The religious folk songs, the tawasheh, the popular biography, the songs of wandering poets and the magicians in Ramadan.

B- Folk music in Egyptian films. Folk music depends on a group of musical instruments of an oriental character, such as: the oud, al-qanun, drums, mazmazza, rababa, rag, sajat, argool, and sesameya, and other instruments that reflect the popular musical sense, which accompany Various social rituals and occasions, such as: the pilgrimage, weddings, weddings, circumcision, birthdays, prophetic praises, the wedding of the Caliph, suitable for Hajj and Umrah ... and other occasions. Many Egyptian films, which deal with the social reality in the countryside and urban in particular, were celebrated with different colors of Egyptian folk music, whether they were: a soundtrack accompanying the movie scenes and their footage, or they were played live by the musical groups that we see on the screen and hear their voice in that. Among the most prominent films that celebrated this type of music

C- Folk songs in Egyptian cinema On the whole, we find that popular songs and their accompanying music have been closely linked to the Egyptian folklore, which were represented in the lyrics of these songs as well as in their melodies and the performance of these melodies with popular instruments that include: drums and tambourines, wind instruments (whistles, horns, trumpets and intentions) Snails, oboe, and argul), stringed instruments (lute, rababa, qanun, tanbura, and sesameya), in addition to other popular instruments such as: cups, bells, sajs, cups, clappers, spoons, spoons, bells, baladi drums, riqq, torr ... etc, those Popular musical instruments that are passed down from generation to generation until they became one of our popular legacies in Egypt with which they perform popular songs, including: "siboo songs", songs for the cradle, dance and play of children, songs of "circumcision", songs for holidays, public occasions, seasons, Ramadan and religious holidays, and Songs of love, weddings and marriage, we also find work songs, songs of pilgrims, there are also songs of "many", a type of 
hymn that was associated with the profession of "meddah" or "scarab", and all of these The songs and others came in popular melodies that will remain immortal in our Egyptian popular consciousness.

In sum, our Egyptian folklore had the upper hand in enriching music and popular singing, with its various heritage materials represented in words, vocabulary, sayings, wisdom, proverbs and old melodies from which musicians drew their popular melodies accompanying songs of all shapes and types to remain expressive of the authentic popular sentiment.

\section{Results:}

1- Cinema can preserve the Egyptian folklore, by combining image and sound, which is unique to this feature (with television), without other means of preserving the heritage.

2- Cinema - alone - we can see through it, the popular visual legacies, in a more attractive, effective and influential way, to a degree that surpasses the way of mere description to the reader on the pages of books.

3- $\quad$ Through cinema, the viewer can see heritage vocabulary and materials, an image, hear it as a sound, and read it in letters ... and this is a feature unique to cinema without all other means of preserving heritage.

\section{Recommendations:}

1- The researcher recommends that the official and non-governmental bodies concerned with preserving the folklore in Egypt adopt the necessary attention to cinema, as one of the means of heritage preservation.

2- $\quad$ The researcher believes that it is necessary to create a "film archive", meaning films (fictional or documentary), related to folklore, to facilitate academic studies and research in this regard.

The researcher hopes that the bodies responsible for the educational process will, in all stages, take films related to folklore as a means for serious folk studies and encourage their owners.

\section{References}

1- Ibrahim Hamadeh (D) - Is drama a beautiful art? . Cairo . Knowledge House. Iqra Series (Issue 435) - 1978.

2- Ahmed Morsi - Introduction to Folklore - Dar Al Thaqafa for Printing and Publishing - Cairo - 1975 AD.

3- Safwat Kamal. Introduction to the study of Kuwaiti folklore. Kuwait .. Ministry of Information. 1986 AD.

4- Abdul Hamid Yunus (d). A defense of folklore. Cairo . Egyptian General Book Authority . 1973AD. 
5- Magdy Aziz. Research Methodology . Cairo . The Anglo-Egyptian Library. 1986 AD.

6- Muhammad Al-Gohary (d) - Folklore Science - Two parts - Dar Al Ma'arif - Cairo - 1981 AD.

7- Nabila Ibrahim (d). Forms of expression in popular literature. Knowledge House. Egypt . 1977 AD.

8- May Al-Tlemceni. Al Hara in Egyptian Cinema (1939-2002). Translated by Rania Fathy. National Center for Translation. Egypt . 2014 m

9- Yaqout Al-Deeb (d). Trends in Film Production in Egypt. Film Prospects Series. Public Authority Palaces Culture. Egypt . 2013 m

10- Ibrahim Hamadeh (d) - Dictionary of Dramatic and Theatrical Terms - Dar Al Shaab Cairo -1971 AD.

11- Abdul Hamid Younes (d). A Dictionary of Folklore. Egyptian General Book Authority . Cairo . 1980 AD.

12- Mahmoud Qasim. The Encyclopedia of Arab Films (C1, C2). Cairo . Rose Al Youssef Press. 2009 AD.

13- Himself - A Guide to Films in the Twentieth Century (in Egypt and the Arab World Madbouly Library - Cairo - 2002 AD.

14- Walaa Muhammad MAHMOUD, MEANS OF MASS COMMUNICATION AND THE POSSIBILITY OF MONITORING THE ELEMENTS OF FOLKLORE UNDER THE AXIS: THE ROLE OF THE MEDIA IN SUSTAINABLE DEVELOPMENT, International Journal of Humanities and Language Research, Vol. 1, No. 2, 2018, pp. 7-12.

Received: January 10, 2019

Accepted: March 14, 2019 